To the Editors:

\title{
Metanephric adenoma mimicking renal cell carcinoma
}

\section{Introduction}

Metanephric adenoma is a rare benign tumour of the kidney, recently recognised as a unique pathological entity which is radiologically indistinguishable from malignant renal tumours. Inability to achieve a precise preoperative diagnosis could lead to a radical surgical approach for this benign tumour with an excellent prognosis. Only a few cases are reported worldwide, and we document the first case in Sri Lanka.

\section{Case report}

A 32-year old man presented with episodic vague left loin pain without urinary symptoms. Ultrasonography and CT scan of the abdomen demonstrated a well circumscribed hyper-echoic solid mass in the left kidney without perinephric or intra-calycial extension (Figure 1). The radiological diagnosis was renal carcinoma and the patient had a radical nephrectomy.

The resected specimen showed well encapsulated tumour measuring $5 \times 5 \times 3 \mathrm{~cm}$ with cystic, necrotic and haemorrhagic areas. Microscopy revealed a well circumscribed tumour composed of solid sheets, glandular forms and papillary forms consisting of small, uniform, ovoid-to-round cells, with scanty cytoplasm and hyperchromatic nuclei. No mitoses were noted. Large areas of necrosis, haemorrhages and psammoma bodies were present (Figure 2). Features were compatible with a metanephric adenoma. It is a rare benign renal tumour which was initially thought to be a tumour of epithelial origin but

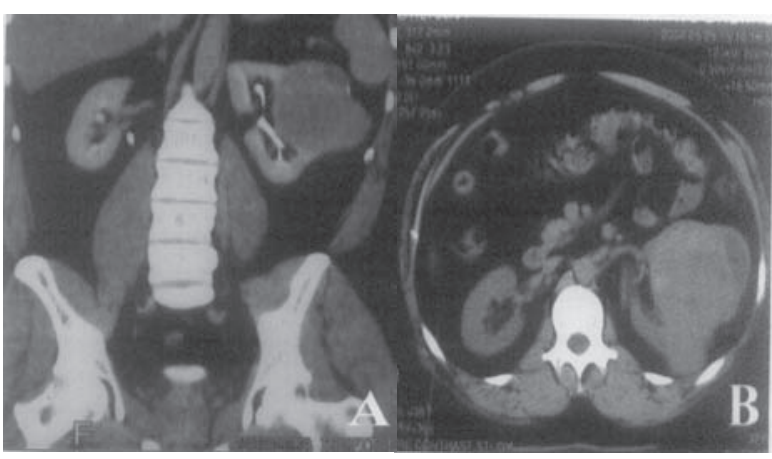

Figure 1. CT scan. longitudinal (A) and transverse (B) views showing metanephric adenoma as a well circumscribed hyper-echoic mass arising from left kidney.

is now considered as an embryological and nephroblastic renal tumour [1,2].

Although benign, metanephric adenoms share some features with Wilms' tumour. Studies on immunohistochemical staining patterns of both tumours reflected developing nephrons. Metanephric adenoma differs from renal cell carcinoma as gains in chromosomes 7 and 17 and loss of the $\mathrm{Y}$ chromosome found in renal cell carcinoma seem to be absent in metanephric adenoma [4]. Most are detected incidentally; other clinical presentations include flank pain with or without fever, haematuria, palpable mass and polychythaemia in adults $[3,5]$.

Because of its benign nature it is important to differentiate metanephric adenoma from Wilms' tumour, low grade renal cell carcinoma, and other benign tumours 


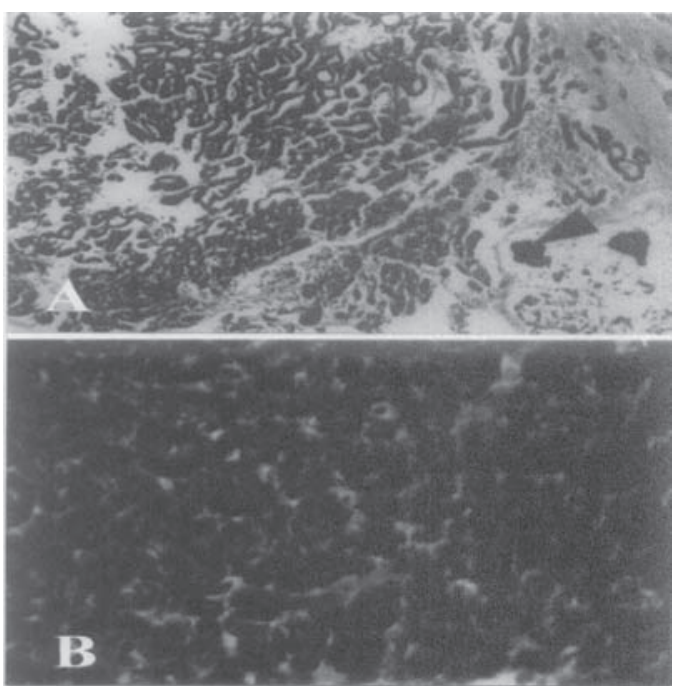

Figure 2. Histological appearance of metanephric adenoma. A (x 10), composed of solid sheets, glandular forms and papillary forms. Psammoma bodies ( - ) are commonly seen, B (x 40), cells are small uniform, ovoid-to-round with scanty cytoplasm and hyperchromatic nuclei. (Haematoxylin and eosin).

with malignant potential. Ultrasonically its well circumscribed nature with hyper-echogenesity and increased attenuation in relation to the adjacent renal parenchyma should raise suspicion. As surgical treatment of renal tumours is largely determined on radiological diagnosis and core needle biopsy is only rarely done, awareness of this tumour enables one to perform an imageguided core needle biopsy to avoid unnecessary radical nephrectomy.

\section{References}

1. Arroyo MR, Green DM, Premlin EJ, Beckwith JB. The spectrum of metanephric adenoma and related lesions: clinicopathological study of 25 cases from the National Wilms Tumor Study Group Pathology Center. American Journal of Surgical Pathology 2001; 25: 433-44.

2. Muir TE, Cheville JC, Larger DJ. Metanephric adenoma, nephrogenic rests and Wilms tumor: a histologic and immunophenotypic comparison. American Journal of Surgical Pathology 2001; 25: 1290-6.

3. Davis CJ Jr, Barton JH, Sesterhenn IA, Mostofi FK. Metanephric adenoma. Clinicopathological study of fifty patients. American Journal of Surgical Pathology 1995; 19: $1101-14$.

4. Brunelli M, Eble JN, Zhang S, Martignoni G, Cheng L. Metanephric adenoma lacks the gains of chromosome 7 and 17 and loss of $Y$ that are typical of papillary renal cell carcinoma and papillary adenoma. Modern Pathology 2003 16: $1060-3$.

5. Chaudhary H, Raghvendran M, Dubey D, Srivastava A, Mandhani A, et al. Correlation of radiological and clinical features of metanephric neoplasms in adults. Indian Journal of Cancer 2004; 41: 37-40.

6. Fielding JR, Visweswaran A, Silverman SG, Granter SR, Renshaw AA. CT and ultrasound features of metanephric adenoma in adults with pathologic correlation. Journal of Computer Assisted Tomography 1999; 23: 441-4.

Neville D Perera, Urological Surgeon, and V Hasanthi Vithana, Research Assistant; Department of Urology, National Hospital of Sri Lanka, Colombo.

Correspondence: NDP, Tel: + 940112691111 and +940112778061.e-mail: <nevi603@sltnet.lk> (Competing interests: none declared). Received 31 January 2005 and accepted 2 April 2005.

Sweet are the thoughts that savour of content;

The quiet mind is richer than a crown;

Sweet are the nights in careless shember spent;

The poor estate scorns fortune's angry frown;

Such sweet content, such minds, such sleep, such bliss,

Beggars enjoy, when princes oft do miss

From Content by Robert Greene (1560 - 1592). First published in 1600 in the collection titled England's Helicon. 